\title{
Anatomical Analysis of the Frontal Recess Cells in Endoscopic Sinus Surgery-An Indian Perspective
}

\author{
${ }^{1}$ Dhingra Shruti, ${ }^{2}$ Agarwal AK, ${ }^{3}$ Passey JC, ${ }^{4}$ Kaul JM
}

${ }^{1}$ Resident, Department of Otolaryngology and Head and Neck Surgery, Maulana Azad Medical College and LNJP Hospital New Delhi, India

${ }^{2}$ Dean and Director Professor, Department of Otolaryngology and Head and Neck Surgery, Maulana Azad Medical College and LNJP Hospital, New Delhi, India

${ }^{3}$ Professor, Department of Otolaryngology and Head and Neck Surgery, Maulana Azad Medical College and LNJP Hospital New Delhi, India

${ }^{4}$ Director Professor, Department of Anatomy, Maulana Azad Medical College and LNJP Hospital, New Delhi, India

Correspondence: Dhingra Shruti, Resident, Department of Otolaryngology and Head and Neck Surgery, Maulana Azad Medical College and LNJP Hospital, New Delhi, India, e-mail: shrudoc@hotmail.com

\begin{abstract}
Surgery of the frontal sinus has gone a full circle from intranasal procedures to destructive and disfiguring external operations and now back to intranasal procedures but with endoscopes. Endoscopic surgery of the frontal sinus has always been a challenging experience because of the narrowness of the area, poor visibility, variable anatomy and encroachment by accessory cells such as agger nasi, frontal, intersinus septal cells on the drainage pathway. With the developments in optical aids such as endoscopes, which provide an angled view, better and brighter illumination, sophistication in the designs of instrumentation and development of imaging techniques, a renewed interest has been created in this area, but the knowledge of anatomy of this area is poor and does not meet the demands of the present day endoscopic surgeon. Moreover, no studies are available on Indian subjects.

Our main interest in the present study was to study the various air cells which encroach the area of frontal recess and would need surgical removal to provide a good drainage and ventilation.
\end{abstract}

Keywords: Frontal recess, frontal recess cells, FESS, agger nasi cells, supraorbital ethmoidal cells, intersinus septal cell.

\section{INTRODUCTION}

Endoscopic surgery of the frontal sinus is a complex procedure due to its anatomic variations and different types of air cells encroaching on the pathway to its ventilation and drainage. Agger nasi cells, frontal cells, supraorbital ethmoidal cells, variations of uncinate process and bulla ethmoidalis can all impede the drainage. To relieve these obstructions requires thorough knowledge of the anatomy of this region before the surgeon can operate with confidence and without intracranial or intraorbital complications. Since it had been difficult to visualize the frontal recess, intranasal surgery of frontal sinus was abandoned by most of the otolaryngologists of the past who then resorted to external operations of the frontal sinus. Recent development of endoscopes, sophistication in endonasal instrumentation and better and brighter illumination has once again created interests and led to the resurgence of intranasal approaches. Difficulties are still experienced particularly in revision cases. This has led to the development of image guided navigational surgery where frontal recess and frontal ostium can be localized more accurately. In spite of these advances, most endoscopic surgeons, even with several years of experience of endoscopic procedures on the nose and sinuses, emphasize the firm grasp of anatomy and variations of this region. Balloon sinuplasty, the most recent and the least invasive technique wherein the drainage of the frontal sinus is dilated, also requires full understanding of the anatomy of this region. The present study was conducted with this aim in view so as to better equip the operating surgeon.

Due to a paucity of literature on Indian subjects, the aim of the present study was to study the various air cells which encroach on the frontal recess and would need surgical removal to provide adequate drainage in the area of frontal recess. 


\section{MATERIALS AND METHODS}

The study was conducted in the Department of Otolaryngology and Head and Neck Surgery and the department of Anatomy, Maulana Azad Medical College, New Delhi. Anatomical dissections were performed on the lateral wall of nose in 30 embalmed adult cadaveric half heads.

Specimens having previous surgery or trauma were excluded from the study. The presence or absence of Agger nasi, frontal, supraorbital ethmoidal cell and suprabullar cell was noted.

Materials used for study:

1. Thirty cadaveric half heads.

2. Vernier callipers.

3. Dissection instruments (including curette, punches, probe, drill, divider, burr).

4. Magnifying glass.

5. Dissection microscope.

6. Image analyzer with appropriate software.

A silicon based impression material, polyvinylsiloxane, an addition type silicon elastomer, light body, usually used in dentistry, with an automatic mixing device, was used for taking impressions of the frontal sinus and its drainage into the infundibulum was studied. This material has a setting time of 180 seconds, and recovers after deformation in $99.50 \%$ cases with a dimensional change of $-0.2 \%$. This material was poured into the frontal sinus after loading it in an injecting device. It traversed the frontal sinus and passed through its natural ostium into the frontal recess in a way that is similar to the flow of mucous in the frontal sinus in the living. After the material was set in about 3-4 minutes, the various cells surrounding the frontal recess and encroaching onto the ostium, which had been previously studied in the cadaveric specimen in detail, were carefully curetted out. This helped us to study the various cells that need removal in order to approach the frontal sinus with the area of the recess being outlined by the silicon material. The entire impression of the sinus, the ostium, the recess and its pathway of drainage in relation to the uncinate, could therefore be accurately studied and measurements taken. .

\section{RESULTS}

Agger nasi cells: Lateral wall of nose in front of anterior attachment of middle turbinate shows a bulge called agger nasi (Fig. 1). On dissection with curettes, needles and probes, it was found to be a solid mound in 24 specimens. Only in 6 specimens (20\%) was it pneumatized (Fig. 2). Degree of pneumatization varied. Only in one case agger nasi cell was large enough to encroach on the frontal recess.

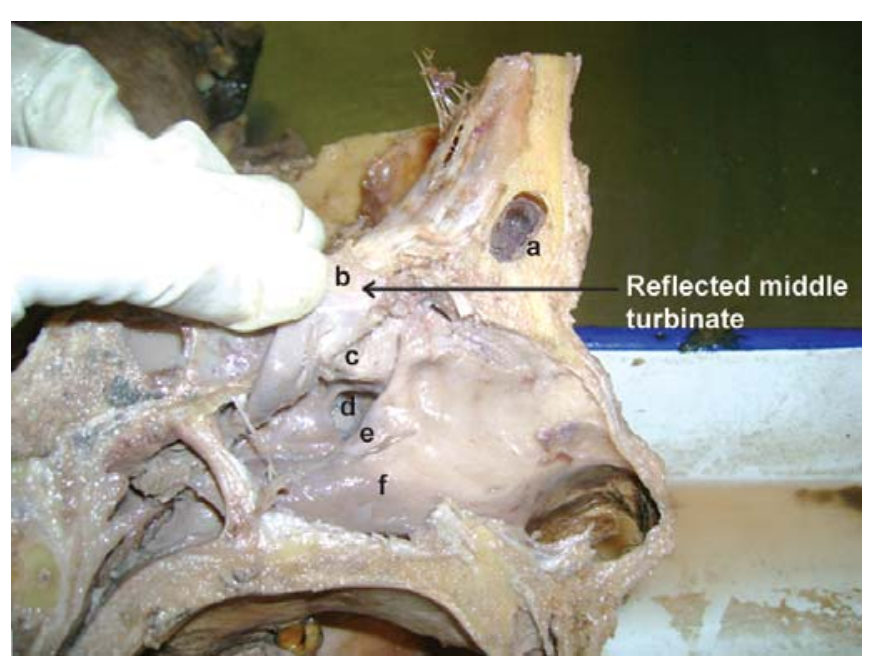

Figure 1: Lateral wall of nose with middle turbinate reflected showing structures as labelled. a: Frontal sinus; b: Reflected middle turbinate; c: Bulla ethmoidalis; d: Maxillary sinus ostium; e: Uncinate process; f: Inferior turbinate

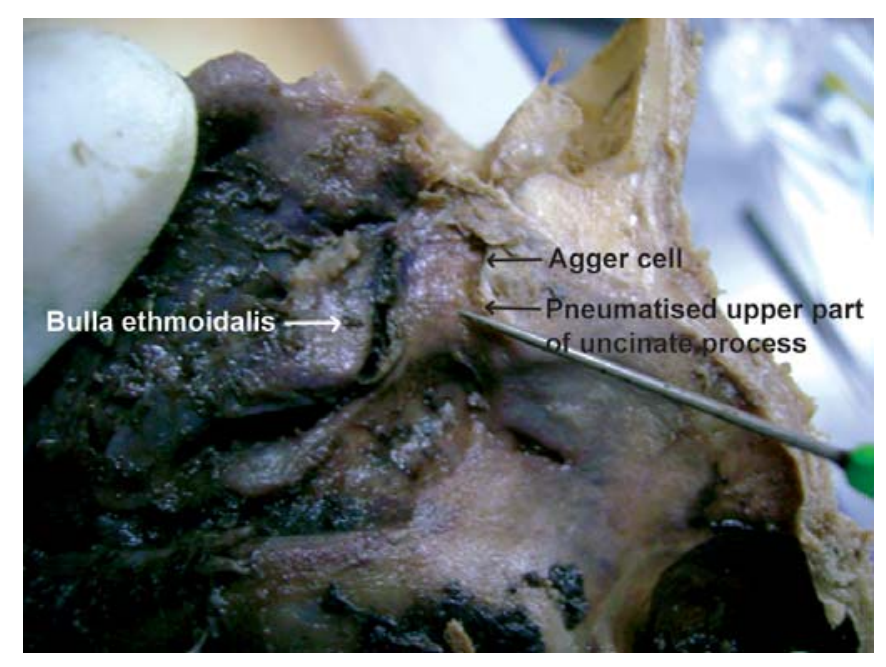

Figure 2: Section showing opened agger nasi cell and pneumatized upper part of uncinate process

Frontal cells: Frontal cells were seen in only $5 \%$ specimens (16.6\%). They were classified according to Bent et al.

Type I cell, i.e. a single cell in the frontal recess above the agger nasi cell was present in 3 specimens, i.e. $10 \%$ (Fig. 3).

Type III cells, i.e. a single cell extending from middle meatus into the frontal sinus was seen in one specimen (3.3\%).

Type IV cells, i.e. an isolated cell within the frontal sinus without an obvious connection to the frontal recess was also seen in one specimen (3.3\%).

Type II cell, i.e. a tier of two or more cells, above the agger nasi cell, may or may not invade frontal sinus, were not seen in any specimens. 


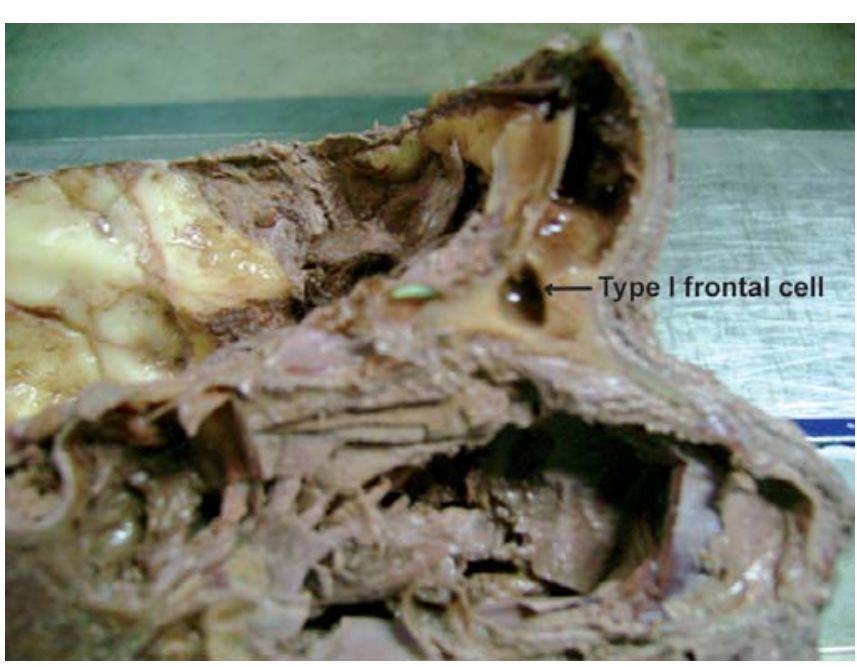

Figure 3: Section showing type I frontal cell (single cell above agger nasi cells not pneumatizing into frontal sinus

Supraorbital ethmoidal cell: They are seen to pneumatize orbital plate of frontal bone. They were seen in only two specimens (6.6\%). In each case their opening was situated behind the bulla ethmoidalis.

Intersinus septal cell: It was not seen in any specimens where intersinus septum was seen. In most of the specimens, this septum had been destroyed.

\section{DISCUSSION}

Frontal sinus and its drainage pathway are seen as an hourglass structure with its "waist", the narrowest part being the ostium of frontal sinus and inferior wider part as the frontal recess. Frontal recess is thus the inverted cone with apex directed superiorly towards ostium of frontal sinus. The ostium has also been called the frontal isthmus. It can be easily seen in sagittal reconstructions of axial and coronal views of CT scan of paranasal sinuses.

Agger nasi cells: The incidence of the presence of agger nasi varies widely in the literature. Bolger et $\mathrm{al}^{1}$ in a review of 200 CT scans found them in $98.5 \%$ while Zinereich et $\mathrm{al}^{2}$ stated that agger nasi cells are present in $100 \%$ and considered them to be normal anatomical structures. Lloyd et $\mathrm{al}^{3}$ stated them to be present in only $20 \%$, though agger nasi was a solid mound in the rest. In anatomical dissections of 30 half-heads, Gaafer et $\mathrm{al}^{7}$ found that agger nasi was just a ridge in $23.3 \%$, while it was pneumatized in $76.6 \%$. Number of cells in agger nasi may also vary. In the study by above authors, agger nasi had a single cell in 14 specimens, 2 cells each in 6 specimens and 3 cells each in 3 specimens. Agger nasi cells pneumatize mostly from the frontal recess or from the ethmoidal infundibulum. Agger nasi cell may be large enough to obstruct the frontal sinus as in one of our specimens. Presently surgery of frontal sinus is surgery in the area of frontal recess and to provide an unobstructed drainage pathway. Removing the prominent agger nasi cell is often the main element in relieving the obstructed drainage. Wormald ${ }^{9}$ stated that agger nasi cell is the "key that unlocks the frontal recess" signifying its clinical importance.

Medial and posterior walls of agger nasi cell are the ones over which the frontal sinus drainage occurs and they are also free standing surfaces. Agger nasi cell must be removed for free drainage. If part of it, more often, the cap, is left behind, it will form adhesions with the surrounding structures, particularly the bulla and obstruct the flow of frontal sinus.

\section{Agger Nasi Cells (\%)}

\begin{tabular}{ccccccc}
\hline Bolger Zinereich & Lloyd & $\begin{array}{c}\text { Del } \\
\text { Gaudio }\end{array}$ & Gaafer & $\begin{array}{c}\text { Landsberg } \\
\text { and } \\
\text { Friedman }\end{array}$ & $\begin{array}{c}\text { Our } \\
\text { study }\end{array}$ \\
\hline 98.5 & 100 & 20 & 86.7 & 76.6 & 78 & 20 \\
\hline
\end{tabular}

Frontal cells: Frontal cells arise above the agger nasi cells and a little posterior to them. They too can obstruct the drainage of frontal sinus. Bent ${ }^{6}$ classified them into 4 types. Type 4 cell is completely within the frontal sinus and may completely obstruct the ostium of the frontal sinus. In such cases, frontal sinus is opaque, due to retention of its secretions while the cell itself may appear as a clear and pneumatized cell like an air bubble in CT scans.

In our study, dissections of frontal sinus showed type 1 cell in 10\%, type 3 cell in 3.3\%, and type 4 also in 3.3\% cases. No type 2 cells were seen.

Del Gaudio ${ }^{8}$ studied 212 sinuses in 106 patients by multiplanar CT scans and found frontal cells in $29.6 \%$ of unoperated cases. Prevalence of different types was type I in $18.6 \%$, type II $2 \%$, type III $6.1 \%$ and type IV $3.1 \%$. According to Schaefer, ${ }^{12}$ frontal cells develop from anterior ethmoid cells after the development of frontal sinus itself.

Meyer et $\mathrm{al}^{10}$ in their study of $768 \mathrm{CT}$ scans showed that frontal cells were present in $20.4 \%$ with type I being the most common (14.9\%). Although incidence of type III and type IV cells was low, incidence of frontal sinusitis was high in these cases.

\section{Frontal Cells (\%)}

\begin{tabular}{lccc}
\hline & Del Gaudio & Meyer & Our study \\
\hline Total cells & 29.6 & 20.4 & 16.6 \\
Type I & 18.6 & 14.9 & 10 \\
Type II & 2 & 1.7 & 0 \\
Type III & 6.1 & 0.7 & 3.3 \\
Type IV & 3.1 & 3.1 & 3.3 \\
\hline
\end{tabular}


Supraorbital ethmoidal cells: These are ethmoidal cells which pneumatize the orbital plate of frontal sinus. According to Kasper, ${ }^{5}$ they develop from the third and fourth frontal furrows. Stammberger ${ }^{4}$ stated that supraorbital cell develops as an extension from the posterior aspects of frontal or the suprabullar recess. Supraorbital cell can also encroach on the frontal recess and impede the drainage and also create difficulties in surgical dissections in this area. Opening of supraorbital ethmoidal cell is always behind the bulla ethmoidalis. Supraorbital ethmoidal cell and frontal sinus may coalesce together but will have two distinct openings, one for each.

In our specimens, supraorbital cells were seen in 2 cases (6.6\%). Their openings were situated behind the bulla ethmoidalis.

Owen and Kuhn ${ }^{11}$ emphasized the surgical importance of these cells. Supraorbital cells displace the posterior wall of frontal sinus and thus encroach on drainage pathway.

\section{Supraorbital Ethmoidal Cells (\%)}

\begin{tabular}{lccc}
\hline Kasper & Van Alyea & Dixon & Our study \\
\hline 8 & 5.8 & 5 & 6.6 \\
\hline
\end{tabular}

Frontal recess, classically described as an inverted funnel shaped area, is a potential space. It may be encroached by several structures such as agger nasi cells, frontal cells, supraorbital ethmoidal cells, variations of uncinate process and bulla ethmoidalis which can change its shape and dimensions. It is also an important area in the etiology of recurrent or persistent frontal sinusitis and to perform uneventful surgery in this area.

Several air spaces open into it - agger cells, frontal cells, supraorbital ethmoidal cell, concha bullosa, bulla ethmoidalis and the lateral sinus.

Thus, this space of frontal recess potentially extends into these structures by continuity and so will be the dimensions. In fact the very structures which limit the boundaries of frontal recess can actually form part of the recess.

\section{CONCLUSION}

With the advent of CT scans and endoscopic sinus surgery, renewed interest has been created in the surgical treatment of diseases of the frontal sinus. Obstruction to drainage and ventilation of the frontal sinus is the main cause of acute and recurrent infection. It is also the main cause in persistent or residual disease. Since most of the endoscopic surgery of the frontal sinus involves its recess, our focus of interest was to study the anatomy of this region in detail.
The study comprised of 30 cadaveric half heads cut sagittally and further dissected to define the area of frontal recess and ostium of frontal sinus.

It was revealed that:

1. Agger nasi region was a solid mound in $80 \%$ while it was pneumatized in $20 \%$. In one case, agger nasi cell was very large and encroached on the area of frontal recess.

2. Frontal cells were seen in only $16.6 \%$ cases. Type I cell was the most common (10\%) while type III and IV were seen in $3.3 \%$ each. No type II cells were seen.

3. Supraorbital cells pneumatizing the orbital plate were seen in $6.6 \%$. Their opening was located behind the bulla ethmoidalis.

Frontal recess is bordered by agger nasi cells anteriorly, bulla ethmoidalis posteriorly, uncinate process inferiorly and middle turbinate medially. Uncinate process is also the key area in deciding the outflow tract of frontal sinus. Several variations can occur in this area and can obstruct the frontal recess.

With the advances in imaging techniques, this area can now be studied in a sagittal plane in addition to coronal and axial ones. In computerized navigational surgery also, the surgeon requires an in-depth knowledge of the anatomy of this area. Most of the anatomical studies made in the past are inadequate to meet the demands of the present day endoscopic surgeon. At present, there is need to further study the anatomy of this area by both meticulous dissections and by multiplanar CT scans with 3D analysis of structures and to correlate the two.

There is also need for uniformity of terminology at international level while describing these structures or those newly identified.

\section{REFERENCES}

1. Bolger WE, Britzin CA, Parson DS. Paranasal sinus bony anatomic variation and mucosal abnormalities. Laryngoscope 1991;101:56-64.

2. Zinreich SJ, Abidin M, Kennedy DW. Cross sectional imaging of the nasal cavity and paranasal sinuses of Op. Tech Otolaryngol Head Neck Surg 1990;1:94-98.

3. Llyod GAS. CT of paranasal sinuses: Study of control series in relation to endoscopic sinus surgery J Laryngol Otol 1990;104:477-81.

4. Stammberger. Functional endoscopic sinus surgery. Mosby. St. Louis 1991.

5. Kasper KA, Nasofrontal connections. A study based on one hundred consecutive dissections. Arch Otolaryngol 1936;23:32243.

6. Bent JP, Spears RA, Kuhn FA, Stewart SM. Combined endoscopic intranasal and external frontal sinusotomy (The above and below approach to chronic frontal sinusitis; Alternatives to obliteration) Am J Rhinol 1997;11:349-54. 
7. Gaafar H, Abdel-Monem MH and Qawas MK. Frontal Sinus Outflow Tract, “Anatomical Study” Acta Otolaryngol 2001;121:305-09.

8. Del Gaudio JH, et al. Multiplanar computed tomographic analysis of frontal recess cells. Arch Otolaryngol Head Neck Surg 2005;131:230-35.

9. Wormald JP.The agger nasi cell: The key to understanding the anatomy of the frontal recess. Otolaryngol Head Neck Surg 2003;129:497-507.
10. Meyer TK, et al. Coronal computed tomography analysis of frontal cells. Am J Rhinol 2003;17:163-68.

11. Owen RJ and Kuhn FA. Supraorbital Ethmoidal Cell. Otolaryngol Head . Neck Surg 1997;116:254-61.

12. Killian (1895) Quoted by Rice DH and Shaffer SD (ed.) Endoscopic paranasal sinus surgery. 3rd ed., Philadelphia, Lippincot Williams Wilkins, 2004. 